ECONOMICALLY SUSTAINABLE

DEVELOPMENT 
This page intentionally left blank 


\title{
ECONOMICALLY SUSTAINABLE DEVELOPMENT
}

\author{
Practical Models for \\ Long-Term NGO Viability
}

BY

RAIF SHWAYRI

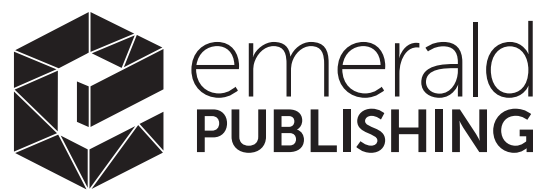

United Kingdom - North America - Japan - India Malaysia - China 
Emerald Publishing Limited

Howard House, Wagon Lane, Bingley BD16 1WA, UK

First edition 2021

Copyright $\odot 2021$ Emerald Publishing Limited

\section{Reprints and permissions service \\ Contact: permissions@emeraldinsight.com}

No part of this book may be reproduced, stored in a retrieval system, transmitted in any form or by any means electronic, mechanical, photocopying, recording or otherwise without either the prior written permission of the publisher or a licence permitting restricted copying issued in the UK by The Copyright Licensing Agency and in the USA by The Copyright Clearance Center. Any opinions expressed in the chapters are those of the authors. Whilst Emerald makes every effort to ensure the quality and accuracy of its content, Emerald makes no representation implied or otherwise, as to the chapters' suitability and application and disclaims any warranties, express or implied, to their use.

\section{British Library Cataloguing in Publication Data}

A catalogue record for this book is available from the British Library

ISBN: 978-1-80043-775-3 (Print)

ISBN: 978-1-80043-774-6 (Online)

ISBN: 978-1-80043-776-0 (Epub)

\section{ISOQAR certified}

Management System,

awarded to Emerald

for adherence to

Environmental

standard

ISOQAR

ISO 14001:2004. 


\section{CONTENTS}

Foreword: From Aid to Development vii

Acknowledgment xi

Introduction: Breaking Away from a Trickle-down Attitude 1

1. Rely on the Locals 5

1. Question Your Incentives. Appreciate Complexities and Traditions 5

2. Make Sense of Industrial Relations 11

2. Think Sustainability First 15

1. Economic Viability: Determine a Critical Size 17

2. Business Modeling 19

3. Build an Integrated Plan of Action 23

1. School-Enterprise Model 24

2. Galbraith Chain: Integration of Cycles and of Communities 25

3. Internal Leveraging to Serve a Common Cause 27

4. Support Higher Education and Applied Research 31

1. Nurture Local Institutions to Train the Leaders of Tomorrow 32

2. Trigger a Research-Oriented Mindset Throughout 35

5. Understand the Need to Structure 39

1. Subsidiarity and Expediency 39

2. System versus Structure 41

3. Plan Your Exit and Transfer Strategies 43

6. Choose Your Assessment Tool: M\&E or ROl? 45

1. Failures of Institutional Monitoring \& Evaluation Tools 45

2. The Importance of Private Investors 47

3. Social Equity 49

7. The Acid Test 51

1. It Takes These Two to Tango: FDI and Exports 55

2. Use Aid Budgets to Activate Sustainable Development 56 
8. Learn to Rejuvenate 59

1. Diversify Your Programs and Operations 59

2. Kill Your Overheads: Yield and Contribution Management 60

Conclusion: Loudison 63

$\begin{array}{ll}\text { Further Reading } & 67\end{array}$

$\begin{array}{ll}\text { Journals } & 67\end{array}$

$\begin{array}{ll}\text { French } & 67\end{array}$

$\begin{array}{ll}\text { Web Journals } & 67\end{array}$

Bibliography $\quad 69$

Index $\quad 75$ 


\section{FOREWORD: FROM AID TO DEVELOPMENT}

I have known Raif Shwayri for many years. We met in 1994 in Brussels when he came to me with his ideas for a development project. We were the same age, had recently taken charge of senior positions at our respective organizations, his in Lebanon, mine in Belgium, and our paths would thereafter coincide. So much so, that I didn't really need to read the manuscript for this book in order to write the preface; however few the following pages, they have taken 26 years to compile if one takes their real measure: the time it has taken to bring the ideas they convey to fruition, to implementation, to revision, and reenactment. And all along, I was there, a sturdy brother-in-arms, debating, arguing sometimes, and sharing in the joy of conceiving new models and giving them wings to fly.

In 26 years, we implemented together some two dozen programs that serve a large population today, programs that have the particularity of being sustainable on all fronts. For sustainability has always been Raif's worry. More to the point, Raif has constantly lived his programs with the anxiety of an entrepreneur who fears what tomorrow brings, anticipating the future before undertaking the present. In doing so, he has set a precedent in our world of development, of accounting for results beyond the scope of a written proposal. Viability of any program is at the heart of all his endeavors, and numerous were the times when we turned away a funded project that did not hold the aptitude to stand alone after implementation.

But sustainability was not his only tool for development. Raif could not foresee any initiative that was not beholden by the locals themselves. His unique experience at standing on both sides of the fence gave him a precious and perceptive outlook on development. An initiative, he says, cannot survive unless it is conceived and appropriated by the people themselves, not devised for them by international organizations, however decent or ambitious their intentions are. In our long years together, I often heard him argue that "you 
can send aid, but development is brewed locally," a statement he repeated in his introduction for this book.

When you take these two concerns of Raif, sustainability and local appropriation of initiatives, and you put them in a shaker, the result is called lasting development. For what is development if not the advancement of the social and economic conditions of a community, done by the locals themselves, and inscribed in a perennial evolution, in respect of traditions, cultures, gender, inclusion principles, and human dignity? Take these two ingredients and thrive with them, and you have the assurance of departing from the shortsighted, selective and detrimental aid to harbor righteous and all-embracing development. It takes this shaker to get from aid to development.

Raif is not only a social entrepreneur but also an alert academic. Having identified his ingredients for development early in his career, he went seeking to systemize his findings in models that can be understood, valued, and shared. I know this because we worked on these models together. The SchoolEnterprise model is a fine paradigm that was met with tremendous success, some of which is related in the following pages. An Education for the Real World is another, so poignant that it became the foundational statement of the university that Raif initiated, a nonprofit institution that embodies the values of real development-a mover and shaker in its own right. And because microentrepreneurs have been at the heart of our development initiatives, it was natural that our crowning achievement spoke to them and became the cornerstone of all our endeavors. The Micro-MBA, a provocative model, disruptive of standardized thinking and one of the "think-out-of-the-box" models that Raif refers to in this book, is the new paradigm that ACTEC is pursuing at this point, recording outstanding results in certain parts of the world already.

Perhaps the successful enterprises that Raif has conducted stem also from the fact that he has acted on them in the spirit of giving. Not the typical philanthropy or aid-governed charity, but the real sense of giving "as a condition of being," to quote his own words. When the mission is pure, to be found outside of one's own persona, the anxiety of the entrepreneur takes a different proportion. The purer the incentive and the more detached, the more elevated the discourse and the objective. And the more anxious the social entrepreneur! There is no doubt that our friendship has grown over the years on the footpaths of development and in its trenches, and it has shone with the smiles of thousands of young people who grew and nurtured with the seeds we have sown. It remains, however, that the initial spark that brought us together in the beginning was there, in the art of giving as a condition of being. The 
story that Raif delivers in the conclusion speaks of that, of the basic and uncomplicated impulse that defines the true wisdom of development.

I have seen this book's story in action, and I testify to its veracity. I would say humbly that somewhere in between the lines, I hear echoes of my own whispers. I say this with the intellectual integrity of someone who has picked the same fight, that of world justice, reasoned and informed, and with the same compelling love of humanity.

From aid to development: with wit, style, and firmness, Raif Shwayri shows us in this book how to cross the ravine.

Daniel Turiel

CEO of Association of Cultural, Technical and Educational Cooperation (ACTEC), Brussels 
This page intentionally left blank 


\section{ACKNOWLEDGMENT}

The book I have delivered here is short, yet the number of people who contributed to its making is great. Because it reflects my lifelong experience in development, it was therefore forged on many anvils, those of colleagues and partners from different organizations and programs. To name them here and now is to recognize their role in clearing the way for the footpath I have walked for 30 years.

My story with development started at a young age. In many respects, I became enmeshed with a social calling early in my teens, thanks to a father who dedicated his life to serving the less fortunate. Nadim Shwayri founded Al-Kafaàt in 1957, writing a large part of his inheritance into an endowment to serve his mission in life. I earned from him the calling, and also the entrepreneurial spirit which characterized most of his undertakings. For me, he was a precursor and a compass for social entrepreneurship.

Along the footpath of development, I was lucky to have met formidable companions and brothers- and sisters-in-arms. Daniel Turiel and Pierre David were the early ones, and those I would take the long ride alongside. From them, I hold the predisposition for quality as a condition of real development. At a time when traditional aid recognizes the fatality of "poor programs for poor people," striving for quality in education and service has become my impetus and prerequisite for development. That's a lesson I learned from them, and it became the feature that brought me together with a large group of activists and doers, many of whom have impacted the course of my actions. If Daniel and Pierre were the companions in building such models as the School-Enterprise, these have seen the light and evolved beautifully because of the concurrence and support of many others over the years. Peter Emmerson, Andy Jong, Maureen Burnley, Cyril Young, Daniel Burton, Nigel Edward-Few, Jeremy Moodey, Guy Caeymaex, Bernard and Véronique Michelet, Marina Bernards, Johanne van Dijk, Josine Westerbeek, Margien Vroom, Miranda Wesselink, Robert van Weldam, Jaap Ronday, André Henneveld, George Shiffer, Rod Evans, Ann Malamah-Thomas, Pierre Berry, Charles Senot, 
Philippe Pracht, Jean-Michel Lacroix, François Sentis, Alain Deccache, Emile Zeizig, Evelyne Foy, Sylvain Benoit, François Allard, Isabelle Turgeon, Jennifer Lemay, Andrés Luna Calvo, Consuelo Baron, Bernard Dujardin, Gilles Barbier, Marie-Hélène Salvignol, Rob Mosry, David Korn, Lionel Cafferini, Abraham Abdallah, Rabih Salameh, Rosemary Ortlieb, Carmelle Bellefleur and Sally Crimmins-Villela are but a few who delve every day, each in his or her way, into making our world just and more equitable. They made it possible for me to learn the lessons which I have presented here, and to try them out.

I acknowledge the early reviewers of the manuscript, James Ketterer, a seasoned educator and development specialist, and Adib Milet, an economist and global entrepreneur, two close friends with whom I have shared in many joys. My grateful appreciation goes to Donna Dixon who edited the manuscript for language, and Nick Wolterman, my publisher at Emerald.

I cannot close without extending a tribute to my wife, Reina KhouryChoueiri, the eternal volunteer who devoted her time, ever since we met, to serving on many development programs. For this, and for her constant support (not without straightening some of my ideas first), I will always be thankful. 